\title{
A criação de visualidade sobre a identidade brasileira: fotografia portuguesa colonial e contemporânea
}

\section{CRISTIANE HERRES}

LORENA TRAVASSOS

Resumo

O presente trabalho se propõe a realizar uma análise inicial sobre a formação da imagem do brasileiro considerando o discurso historicamente construído e reforçado na fotografia colonial. Tal visualidade resiste através dos tempos, consistindo em uma forma de colonialismo contemporâneo por caracterizar-se como uma ação reducionista das identidades, em dissimulação de uma ideologia globalizada. A possibilidade de criação de paradoxo a esses discursos é analisada por meio da reflexão sobre o trabalho de André Cepeda e Miguel Valle de Figueiredo, fotógrafos portugueses com trabalhos fotográficos, jornalísticos ou artísticos, acerca do brasileiro.

Palavras-chave:

Visualidade, colonialismo, imagem do brasileiro 


\title{
The creation of visuality on the Brazilian identity: Portuguese colonial and contemporary photography
}

\author{
AUTORA
}

\section{Abstract}

This study aims to carry out an initial analysis of how the Brazilians' image is shaped by a discourse that is historically constructed and reinforced by colonial photography. This visuality has endured through the ages and represents a form of contemporary colonialism, as it is characterized by an identity reductionism disguised as a global ideology. The possibility of countering these discourses is analyzed by reflecting on the work of André Cepeda and Miguel Valle de Figueiredo, two Portuguese photographers who have developed photographic, journalistic or artistic works about the Brazilian people.

Keywords: Visuality, colonialism, Brazilians' image 


\section{La creación de visualidad sobre la identidad brasileña: fotografia portuguesa colonial y contemporánea}

\section{AUTORA}

\section{Resumen}

Este estudio pretende realizar un análisis inicial de cómo la imagen de los brasileños está conformada por un discurso que históricamente se construye y se refuerza con la fotografía colonial. Esta visualidad ha perdurado a lo largo del tiempo y representa una forma de colonialismo contemporáneo, ya que se caracteriza por un reduccionismo identitario disfrazado de ideología global. La posibilidad de contrarrestar estos discursos se lleva a cabo reflexionando sobre el trabajo de André Cepeda y Miguel Valle de Figueiredo, dos fotógrafos portugueses que desarrollaron trabajos fotográficos, periodísticos o artísticos, sobre el pueblo brasileño.

Palabras clave:

Visualidad, colonialismo, imagen del brasileño 


\section{Introdução}

A estetização da vida social, bem como do conhecimento sobre realidades distantes geográfica e historicamente, avançou, no século XIX, devido à invenção e ao uso das tecnologias de captação e reprodutibilidade da imagem, como a fotografia. Também a utilização desse recurso, o registro fotográfico, para reafirmar os poderes imperialistas e colonizadores não são novidade. Estuda-se largamente o uso da fotografia para registrar civilizações e indivíduos que se distanciavam dos europeus, entendendo aqueles como seres inferiores, selvagens e incapazes. Tal uso da fotografia cria o conceito de fotografia colonial, ou seja, aquela que registra o discurso do colonizador, que, por sua vez, se coloca em um lugar de superioridade em relação a quem está sendo captado por sua câmera, como que desvelando o mundo desconhecido e bárbaro.

A reafirmação na Europa - e mesmo nos Estados Unidos - da modernidade crescente entendida como "o lógico produto final de uma larga evolução linear" (MIRZOEFF, 2003, p. 186) é reiterada na fotografia colonial pela oposição apresentada nas imagens entre os seres retratados e aqueles que retratam. Nas imagens produzidas, acentua-se o distanciamento histórico, dando a perceber que as figuras ali registradas vivem em uma época há muito ultrapassada pela civilização ocidental coetânea a essas imagens. A fotografia colonial serviu, nesse sentido, para a exposição da imagem do "Outro", introduzindo essa apresentação do exótico mundo primitivo na sociedade moderna ocidental, ao mesmo tempo em que reafirmava a superioridade desta, ou seja, do colonizador sobre o colonizado, dado que o poder sempre está do lado de quem possui os meios. 
A fotografia, por esse aspecto, conforme afirma Barradas (2009, p. 6o), constitui, por meio de seu poder simbólico, uma "reprodução das relações de dominação e subordinação e, portanto, das relações coloniais". Assim, o visual é visto como parte fundamental para a "criação e manutenção das relações de produção capitalistas, cujas origens remontam ao período colonial", período em "que não eram reproduzidos apenas [relações hierárquicas] de classe, mas também de região, cultura, língua e, principalmente, de raça" (apud BARRADAS, 2009, p. 59). A fotografia, nesse contexto, desempenha um papel imperativo na perpetuação de concepções e valores que produzem um discurso hegemônico, que pode tanto contribuir para uma emancipação social como fomentar relações de desigualdade.

A fotografia surge, ainda, como veículo fundamental na representação do outro, devido a sua rapidez e suposta exatidão na reprodução da imagem. Aliás, "a fotografia começou, historicamente, como uma arte da pessoa: da sua identidade, do seu estado civil, daquilo a que se poderia chamar, em todas as acepções da expressão, o quanto-a-si do corpo" (BARTHES, 1984, p. 89). Para William Ewing (1996), todas as fotografias do corpo são políticas, visto que representam valores e atitudes sociais. Este é o ponto central que relaciona a fotografia e a construção de uma identidade corporal.

Tais implicações podem ser acompanhadas ao longo do tempo até se chegar à atualidade, quando as fotografias realizadas estampam as fragilidades das relações constituídas entre diferentes sociedades. A depender das intencionalidades para a composição de imagens fotográficas, o registro do olhar de uma sociedade sobre a outra pode gerar o estranhamento e acentuar o distanciamento, impossibilitando o diálogo e a convivência. Pode, entretanto, caminhar no sentido contrário, descortinando aquilo que foi obscurecido pelos discursos hegemônicos e promovendo uma aproximação daquilo que soa diferente, porém constituído a partir do que todos têm em comum, que é a sua humanidade.

Para efetuar uma reflexão sobre as questões acima pontuadas, este trabalho propõe-se a dialogar com alguns trabalhos artísticos contemporâneos, a fim de provocar uma análise sobre as construções atuais de imagem de brasileiros - e que se constitui uma visualidade peculiar - por fotógrafos portugueses, empreendendo uma discussão sobre as representações de um olhar sobre o Outro e considerando a realidade histórica vivida e que não mais se apresenta como 
colonizadora. As reflexões serão efetuadas na experiência contemporânea da criação de discursos imagéticos, por meio da análise de alguns trabalhos realizados pelos portugueses Miguel Valle de Figueiredo e André Cepeda, fotógrafos das paisagens e de personagens brasileiros.

O olhar do português torna-se importante neste contexto, pois foram os colonizadores os primeiros a divulgar uma imagem do Brasil para o mundo, seja por meio das cartas ao rei de Portugal enviadas por D. Pero Vaz de Caminha, seja, posteriormente, por meio da fotografia de "tipos" com as cartes de visite $e^{\prime}$ laboradas pelo fotógrafo português Christiano Júnior, possuidor da maior coleção de fotos de escravos produzidas ainda no século XIX.

\section{A fotografia e a construção de visualidade}

A onipresença da fotografia no século XX fez com que Walter Benjamin previsse ainda em 1921 (BENJAMIN, 1992) que haveria um dia em que o número de revistas ilustradas seria maior que o de caçadores em época de caça. Vive-se, na atualidade, uma imensa proliferação de artefatos visuais, o que permite-nos dizer que a experiência humana é mais visual que nunca, refletindo dessa forma a centralidade do olhar na cultura ocidental (JENKS, 1995). A estetização da vida social moderna e contemporânea estabelece-se na enorme quantidade de suportes e veículos que utilizam a visão, como revistas, jornais, televisão e cinema.

Segundo Guattari (1992, p. 15), o uso das tecnologias (incluída aí a tecnologia de produção da imagem) pode gerar "simultaneamente uma tendência à homogeneização universalizante e reducionista da subjetividade [seja individual ou coletiva] e uma tendência heterogenética, quer dizer, um reforço da heterogeneidade e da singularização de seus componentes". O autor alerta, porém, para "a mass-midialização embrutecedora, à qual são condenados hoje em dia milhares de indivíduos" (GUATTARI, 1992, p. 16). Nesse embrutecimento, o indivíduo vive a experiência de olhar na superfície da imagem, deixando-se absorver por ela, arruinando a relação subjetiva e complexa com o objeto retratado e estabelecendo uma opaca relação-ritual constituída no discurso imagético.

Se por neocolonialismo entende-se a situação política e econômica atual que "resulta, exatamente, do conjunto das estratégias privadas de grandes grupos industriais e financeiros" e que incrementa as dívidas dos países periféricos e "recoloniza o Ter- 
ceiro Mundo" (BRAGA, 200o, p. 62-63), aqui entende-se o colonialismo contemporâneo abordado, no campo da construção das imagens, como um campo complexo de tensões e movimentos na criação de visualidades que expressam, entre muitos temas, o olhar de uns sobre outros - países centrais e períféricos -, mas também de indivíduos sobre si mesmos e sobre sua coletividade.

$\mathrm{Na}$ conformação de uma visualidade, o juízo sobre algo define-se a partir de sua reificação pelo discurso construído. A visualidade é o exercício de transformar a percepção sobre a realidade, inicialmente realizada pelo indivíduo na sua experiência direta com o objeto a ser conhecido, naquilo que as imagens apresentam, considerando que estas traduzem a realidade em algo que pode ser compreendido e captado mais rapidamente do que outras semioses. Tal discurso conforma-se como instrumento de poder sobre o objeto reificado, uma vez que se podem elaborar, por meio desse processo, estratégias e/ou métodos que disciplinem o conhecimento da realidade, conduzindo o entendimento sobre ela. Essa prática, amplificada no gesto de olhar de cada indivíduo, é, portanto, o mecanismo de entendimento e interpretação da realidade. Nessa dinâmica, cada espectador se torna potencialmente difusor de um sistema interpretativo peculiar ao atual sistema hipercomplexo e globalizado.

A visualidade se constitui, portanto, em "uma prática sócio-cultural complexa e heterogênea, cuja relação com o real [...] não é necessariamente mimética nem de contiguidade", mas agencia "as relações que se estabelecem com o sistema cultural envolvente" (GIL, 2011, p. 22-23)

Especificamente nesye texto, considera-se a fotografia como elemento fundador no processo de criação de visualidades, uma vez que, por seu mecanismo, além de reificar o objeto retratado, provoca-se maior acesso ao que foi retratado por meio de sua reprodutibilidade. A análise dessas visualidades criadas busca promover o entendimento de práticas e conhecimentos específicos que constituem as relações sociais, bem como aquelas que implicam a criação e a atribuição de identidades, tanto individuais quanto coletivas e que, por sua vez, respondem por muitas das conformações de olhares sobre o Outro.

\section{A fotografia e a construção identitária do Outro}

Segundo Juan Naranjo, na introdução do livro Fotografia, antropologia y colonialismo (2006), os avanços da tecnologia de impressão de imagens, iniciados a partir do início do sécu- 
lo XIX, permitiram a expansão da circulação das imagens impressas de uma forma superior aos séculos anteriores. A proliferação da utilização de dispositivos ópticos, tanto no setor público como privado, modificou os hábitos sociais, introduzindo mudanças nas formas de recepção e distribuição da informação. Apenas na segunda metade do século XIX, foi criada uma "indústria visual" com incrível densidade iconográfica.

A fotografia passou então a desempenhar um papel fundamental na transformação cultural, especialmente a partir do momento em que a imagem foi posta junto à palavra impressa, apesar de a fotografia apagar as fronteiras entre a realidade e sua representação. Foi justo a mimese ilusória, que a fotografia forneceria entre o objeto e sua imagem, além de sua capacidade de multiplicação, que tornou a fotografia uma das mídias com maior penetração social. Os avanços nos processos fotográficos possibilitaram o surgimento de sua indústria, abrindo espaço para a comercialização em larga escala de fotografias a preços econômicos, a exemplo das cartes de visite. Ao adquirir longo alcance, iniciou-se um amplo processo de democratização da informação visual, posto que a aquisição da fotografia substituía a experiência direta pela observação virtual das pessoas e paisagens de locais distantes.

Devido à expansão da indústria fotográfica e ao aumento do consumo de fotografias, muitas empresas ampliaram sua oferta e, como se necessário fosse, inventariaram o mundo enviando fotógrafos a todos os lados do planeta para documentar o que viam. Ao mesmo tempo, em sítios distantes foram abertos numerosos estúdios fotográficos que cumpriam dupla função: a de fotografar a burguesia local, os colonos, missionários, marinheiros e a de fotografar tipos humanos que chegavam nas principais cidades e portos. O objetivo era a aquisição dessas imagens pelos viajantes e turistas.

O início da grande circulação de fotografias tornou "familiar" a imagem do Outro, tanto para a classe científica como para a burguesia da época. Apesar de alguns pesquisadores, como os antropólogos, utilizarem essa sorte de imagens para análise em detrimento da pesquisa de campo, outros estudiosos contestavam a veracidade dessas imagens, a exemplo das cartes de visite, por terem, sobretudo, um potencial comercial. Os estudiosos contrários ao uso dessas imagens asseveravam que elas apresentavam um padrão preestabelecido para que as informações alcançassem melhor compreensão e para facilitar a comparação e, por isso, raramente iriam servir como base de estudos científicos sérios. 
As fotografias realizadas no período colonial europeu apresentavam, muitas vezes, um quadro totalmente falso de acontecimentos, sujeitos e circunstâncias históricas (ROBERTS, 1988). Os temas eram inventados em modos genéricos e não havia esforço para identificar o fotógrafo e o acontecimento com profundidade. Por isso, é preciso utilizar a fotografia da época colonial de forma crítica $^{2}$, desafio muito importante para quem utiliza a análise fotográfica em pesquisas científicas até hoje.

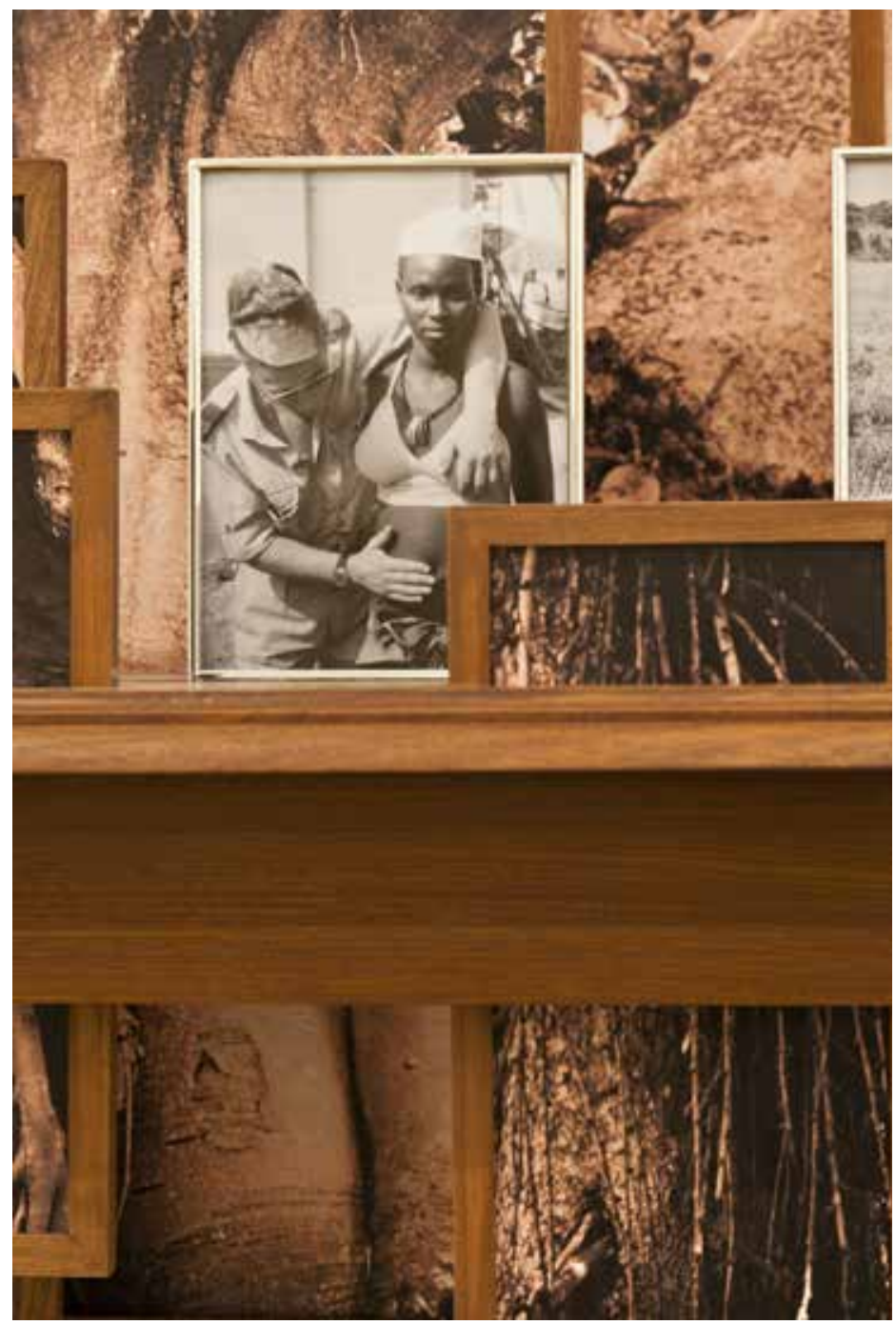

Figura 1 - Botânica

Fonte: ARAÚJO, Vasco. Exposição Botânica, detalhe do "objeto escultórico" (2014)

Disponível em: $<\underline{h t t p: / / w w w . ~}$ museuartecontemporanea.pt/ programs/view/5>. Acesso em: 2 maio 2017 
A contaminação do comportamento europeu nos modos de vida das tribos retratadas, que muitas vezes levou ao extermínio total dessas culturas, foi outro fator responsável por tornar as fotografias comerciais coloniais inutilizáveis em pesquisas antropológicas. Grande parte desse tipo de fotografia reproduzia todo o tipo de fantasias relacionadas com o orientalismo e outros exotismos. Desse modo, tais fotografias foram utilizadas para criar identidades estereotipadas que satisfaziam aos consumidores românticos europeus.

Há também fortes relações de gênero que permeiam a fotografia da época colonial, pois, naquele momento, era atribuído um papel inferior às mulheres, especialmente àquelas não europeias. Fotografias de mulheres seminuas ou mesmo nuas, independente da raça e do país colonizado, são sempre presentes na visualidade colonial, o que pode ser explicado, segundo Felipa Vicente (2014, p.22), como "resultado de uma dominação em relação ao visível - em relação àquilo que pode se tornar visível - assim como da hegemonia masculina no espaço colonial". Entre os problemas éticos que estas imagens colocam, Vicente (2014, p.26), ao se deparar com as obras escultóricas de Vasco Araújo, intituladas Botânicaz (Fig. 1), aponta: "[...] Mas se ela fosse a sua mulher, esposa, branca, numa aldeia portuguesa e não em África, o soldado português deixar-se-ia assim fotografar por alguém?"

Para Stuart Hall, em "Cultural identity and diaspora" (200o), as práticas de representação implicam sempre posições a partir das quais escrevemos ou discursamos. A caracterização do Outro contribuiu para a criação de categorias religiosas, raciais, sexuais e de gênero articuladas de formas variadas. Esse propósito frívolo de identificação de diferenças desempenhou papel fundamental na cultura visual ocidental. Ao criar o Outro como um ser desqualificado, inferior em relação ao poder e ao saber ocidentais, a produção ocidental constituiu-se como forma de conhecimento hegemônico. Assim, utilizou-se e apropriou-se da existência e da cultura do Outro devido a sua superioridade.

Essa ideia dialética de mundo, que contrapõe o colonizador e o colonizado, sendo a cultura do colonizador superior, além de produzir uma subalternização do Outro, incutiu profundamente a ideia de inferioridade na mente deste, para que se considerasse incapaz de combater essa lógica. A fotografia foi responsável por construir, muitas vezes, a aceitação de um poder autoritário sobre o sujeito fotografado, poder que também controlava a produção e a distribuição das imagens 
(BARRADAS, 2009). Essa assimetria de poderes levou à percepção de que as pessoas negras, sobretudo as mulheres, são sub-humanas. As imagens que mostram posições erotizadas da mulher, com nudez e aparente disponibilidade sexual ao branco colonizador, colocavam-na não num mundo imoral, mas amoral, pois sua existência está alicerçada fora dos padrões estipulados pela moral colonizadora.

\section{A imagem do brasileiro: um breve contexto inicial}

A invenção do clichê "brasileiro", ou seja, a criação de uma visualidade que pudesse traduzir o que, para determinado grupo de indivíduos, constituía o habitante original do dito Novo Mundo, é um produto da história da imigração portuguesa para o Brasil. No intuito de construir um entendimento sobre as questões atuais, pode-se afirmar que esse clichê agrupa em si uma pluralidade de imagens. Além de o termo "brasileiro" representar um bárbaro selvagem, também foi utilizado para representar o emigrante português ou "torna-viagem" ao regressar do Brasil. Neste último sentido, nomeadamente no século XVIII, o termo "brasileiro" sofria ondulações de sentido de acordo com a experiência vivida pelo português emigrante. Se obtivesse sucesso, seria socialmente edificante; com o insucesso, seria um desqualificativo. Diante desse jogo, o estereótipo ambíguo relacionado ao brasileiro mediava a relação difícil entre o que se era e o que se queria ser na sociedade portuguesa. Segundo Jorge Fernandes Alves (2004, p. 195), a consequente falta de oportunidades devido à economia marcada pela lavoura e à estagnação do crescimento econômico em Portugal outorgava ao Brasil a possibilidade de um futuro melhor: "Emigrar significava ir ao encontro de aspirações construídas no confronto com o meio e representações sociais nele dominantes, apoiadas no exemplo de figuras reais e próximas".

A mais antiga representação do brasileiro pelo português materializa-se na carta ao El Rei de D. Manoel de Pero Vaz de Caminha, no primeiro dia de maio de 1500 . Seu relato sobre o Brasil era composto não só por descrições como por conjeturas do que era visto. Inicialmente, os índios foram considerados bárbaros e, por isso, deveriam ser amansados pela fé cristã. Segundo Caminha, "apesar de tudo isso andam bem curados, e muito limpos... São como aves, ou alimárias montesinas, as quais o ar fez melhores penas e melhores cabelos 
que às mansas [...]". Logo após essa curiosidade inicial, os índios foram vistos como canibais, totalmente detestáveis, mas suscetíveis ainda de salvação (ARROYO, 1963, p. 22). Naquela época, o nativo brasileiro era descrito por meio dos relatos e pinturas dos viajantes que lá estavam ou estiveram. Com a chegada dos escravos vindos da África, a partir do século XVI, muda-se a fisionomia do lugar, mostrando o Brasil como uma nova civilização marcada por singularidades e, principalmente, africanidades. Devido a essa mistura de nacionalidades, os habitantes parecem aos olhos europeus como gente bizarra, o que, somado à tropicalidade índia, os qualificaria como exóticos (RIBEIRO, 1995).

No Brasil, como já foi dito, muitos fotógrafos se concentraram nas regiões portuárias, onde desembarcavam os escravos e as autoridades. Entre os fotógrafos portugueses no Brasil, o açoriano José Christiano Júnior possuía a maior coleção de fotografias de escravos realizadas nos anos 1860. Com uma coleção composta por 77 fotos, ele oferecia à clientela uma "variada coleção de costumes e typos de pretos, cousa muito própria para quem se retira da Europa" (GORENDER, 1987, p. XXXI). Assim como o autor fotografava os escravos no exercício de suas funções (Fig. 2), o que demonstra o interesse quase de classificação dos brasileiros existentes, há aquelas fotografias que se referem às mulheres negras como que expondo seu corpo a ser possuído por seu dono. São mulheres apresentadas nuas, objetificadas, o que remete a como os escravos eram examinados detalhadamente nos mercados. Mais que isso, conforme aponta Freitas (2011, p. 65), as escravas eram alvo da luxúria dos senhores e para elas eram dirigidas toda sorte de ações no âmbito sexual, uma vez que eram "tidas como meros objetos" que "davam vazão a impulsos sexuais."

José Christiano Júnior (Açores, Portugal 1832 - Assunção, Paraguai 1902) imigrou para o Brasil em 1855, fixando-se primeiramente em Maceió, onde exerceu a atividade de fotógrafo. Em 1860, mudou-se para o Rio de Janeiro, retratando africanos escravos ou libertos, seja enfocando as características que distinguiam as pessoas de origem africana, seja simulando atividades profissionais em estúdio (Fig. 2). Além dessas imagens, seu ateliê comercializa retratos em ambrótipo4, reproduções de gravuras, paisagens para estereoscópio, fotografias ampliadas sobre lenços, porcelana e marfim, cartes de visite de monarcas, militares, entre outros. 

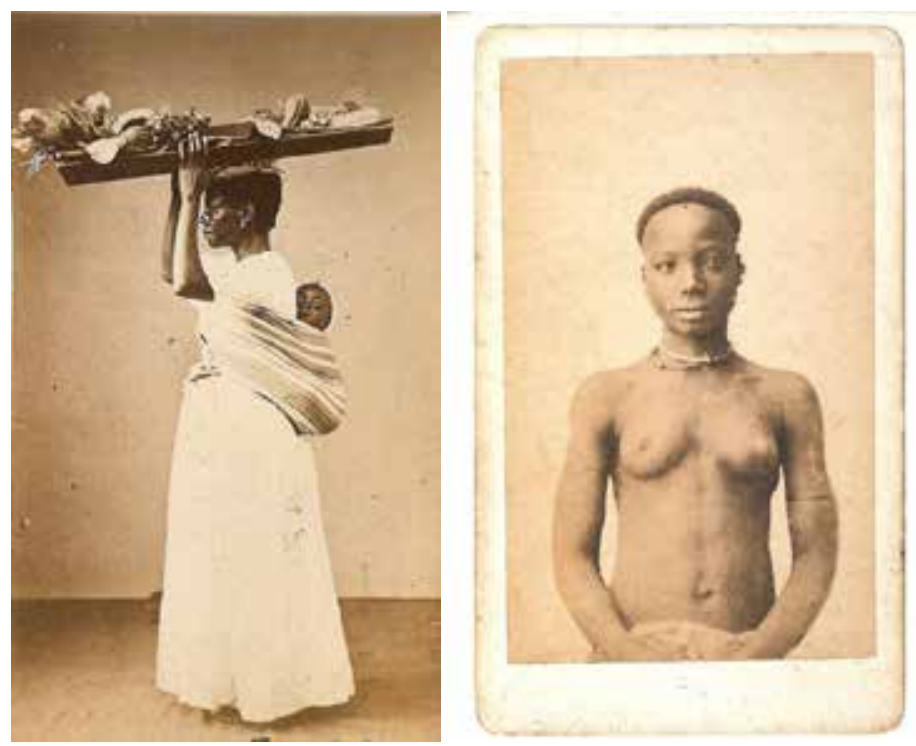

Figura 2

Escrava vendedora de frutas

Figura 3

Mulher negra

Autoria:

José Christiano Júnior, 1865.

Fonte: LISSOVSKY, M. ; AZEVE-

DO, P. C. O fotógrafo Cristiano

Jr. In: Escravos brasileiros do

século XIX na fotografia de

Christiano Jr. São Paulo: Editora

Ex Libris, 1987. p. ix-xv
No período em que viveu no Rio de Janeiro, a sua mais importante produção era a coleção de cartes de visite de africanos. Os negros daquela época colonial eram mais da metade da população da capital do império português, compondo um "contingente tão expressivo que cronistas do período chegaram a comparar a paisagem carioca às cidades do litoral africano" (LISSOVSKY; AZEVEDO, 1987, p. XXII). Christiano Júnior apresentava em suas cartes de visite "tipos de preto", ou seja, em suas fotografias os negros eram dispostos frontal e lateralmente para mostrar traços faciais, marcas de tribos e vestimentas para realçar características próprias que definiam cada etnia e/ou profissão (técnica conhecida como bertillonage).

Essas fotografias, segundo Lissovsky e Azevedo (1987), eram direcionadas ao público que esteve isolado do mundo até 1808 , ano que em que houve a abertura dos portos brasileiros para o comércio internacional, o que acontecia concomitantemente com a instalação da corte portuguesa no Brasil. Trata-se de um conjunto de imagens que evoca tipos humanos e ofícios; basicamente são fotos de um estrangeiro e para estrangeiros. Ressalta-se a ondulação de sentidos que alcança a carte de visite, a saber, se houvesse a imagem de um senhor de posses, poderia, então, se tornar o seu cartão de visita; no entanto, quando se apresenta o retrato do negro, ou "tipos de preto", teria a função de cartão-postal do Brasil. Enquanto o primeiro descreve uma pessoa digna e singu- 
lar, o último descreve um personagem pitoresco e genérico (CUNHA,1987). Claro que o fato de nunca terem registrado "tipos de branco" na história mundial contribui, também, para que as cartes de visite com imagens de europeus tivesse a característica de cartão de visita.

Enfatizam-se, aqui, os comportamentos que constituem e que são divulgados sobre a história da sexualidade no Brasil Colônia, ainda que a sexualidade tenha sido vivida entre reprimendas da Igreja e o liberalismos dos primeiros colonizadores:

Aos olhos dos jesuítas, sempre queixosos das dificuldades da catequese, do clima, e da falta de recursos, o frenesi sexual campeava, antes de tudo, entre os índios: sempre nus, poligâmicos, incestuosos. [...] em relação aos primeiros colonos... quase todos... não satisfeitos em fazer suas escravas de mancebas, lançavam-se às livres, pedindo-as aos índios por mulheres (VANIFAS, 1997, p. 232-233).

Assim, os olhares sobre os corpos dos indígenas e dos escravos carregam a lascividade do processo da escravidão, mas também do crescimento populacional ocorrido no período colonial e que torna o Brasil um país mestiço.

De acordo com DaMatta (1984), na literatura brasileira, ainda no século XIX, surgiu o primeiro 'malandro' associado à identidade do brasileiro, com o livro Memórias de um sargento de milícias, de Manuel Antônio de Almeida, que apresentava o personagem Leonardo Pataca como um mulherengo e criador de problemas. Originado nos contos populares da Península Ibérica, o personagem Pedro Malasartes chega ao Brasil no final dos anos 1930 e passa a representar o brasileiro trapaceiro, sem escrúpulos nem remorso. Assim, o malandro foi definido como um "profissional do jeitinho e da arte de sobreviver nas situações mais difíceis” (DAMATTA, 1984, p.102).

Sérgio Buarque de Holanda, em Raízes do Brasil (1963), tratou de uma cordialidade que parecia emanar da alma do povo brasileiro, tornando-o por excelência gentil e pacífico. Afinal, se os portugueses, bem como quaisquer outros estrangeiros, se adaptaram tão bem ao Brasil é porque a cultura brasileira seria mais maternal e acolhedora. Esse princípio de cordialidade, segundo o autor, teria sido favorecido pelo processo inicial de formação do brasileiro no interior da junção de tantas etnias. Dado que o Brasil se originou da mistura entre vários grupos raciais e culturais, a tolerância pode 
ter surgido como sentimento espontâneo. No entanto, lembra Darcy Ribeiro (1995, p.167-168), o processo de formação do brasileiro, devido a esse conjunto dos contingentes que lá habitavam, foi altamente conflitivo, com enfrentamentos de ordem étnica, social, econômica, religiosa e social que vêm desenhando a sociedade brasileira desde então, desconstruindo assim a imagem ontológica de "homem cordial" defendida por Holanda. Ainda segundo Ribeiro (1995), os conflitos interétnicos sempre existiram, especialmente entre uma tribo e outra, o que foi intensificado com a chegada dos europeus e a política expansionista.

Cavalcante (2005) afirma que a imagem negativa do malandro foi cristalizada na identidade do brasileiro a partir de 1943, durante a Segunda Guerra, após uma visita de Walt Disney ao Brasil devido à chamada política de boa vizinhança dos EUA. Naquele ano, o Pato Donald apresentaria o seu novo amigo Joe Carioca, ou Zé Carioca (como conhecido no Brasil), papagaio simpático que habitava os morros do Rio de Janeiro e que levava a vida com o famoso jeitinho brasileiro. Foi criado assim um dos estereótipos mais poderosos e persistentes correlacionados à identidade brasileira: o malandro, aquele que sempre encontra um jeitinho para superar adversidades, mesmo que isso prejudique outras pessoas. A imagem do Zé Carioca unia o exótico e o malandro em um só personagem, forjando uma identidade homogênea relacionada ao suposto caráter do brasileiro: "dali em diante, a imagem do brasileiro se firmava como a de uma espécie de bon vivant tropical, cheio de ginga, que não se adaptava a empregos formais e vivia de "bicos'" (CAVALCANTE, 2005, p. 71-72). Estava assim criado um estereótipo brasileiro que foi recebido e assimilado em todo o mundo.

De acordo com Luciana Pontes (2004, p. 236), que parte de um trabalho de campo realizado em Lisboa sobre as mulheres na mídia, "a recente intensificação, no final dos anos 90, da imigração brasileira complexificou os processos identitários mútuos, num quadro em que são criadas e/ou reforçadas velhas representações". Nessas representações, a autora afirma que são verificados processos de essencialização e exotização da identidade nacional brasileira, além da sexualização das mulheres. Tal sexualização, como visto, acompanha a formação do Brasil e a utilização da fotografia colonial para representação do Outro, experiência determinada pelo poder autoritário da cultura europeia sob o território geográfico e corporal dos povos colonizados. 
Portanto, podemos dizer que as peculiaridades do atual entendimento sobre o corpo do brasileiro, especificamente aquele conformado pela mídia, são revestidas de novos processos colonizadores, em que à imagem do brasileiro associa-se a cordialidade, mas também a sensualidade e a alegria, impregnadas pelas festas e por certa displicência na produtividade.

\section{Discursos diversos: possibilidade de conformação complexa da visualidade sobre a identidade brasileira}

A existência e a ação do indivíduo em sua realidade tal qual esta se apresenta são condicionadas pela diferença de modos de olhar o mundo, de interpretá-lo e de possuí-lo. Os vários atravessamentos e atualizações elaborados a partir de um mesmo objeto ou acontecimento percebido instituem-se como diferença (différances), algo concebível, porém irrepresentável, que imprime sempre a possibilidade do outro e do novo. Um jogo que produz o movimento entre o que se vê e como se é tocado pelo que se vê, provocando o reconhecimento do que é próprio do ser na distinção do outro. Tal diferença constrói-se, segundo Derrida (1968, p. 41), não no momento de apreensão imediata do objeto que está sob a percepção do indivíduo, mas em "um contato feito com aquilo que já está inscrito, inconscientemente, na memória" (HARLAND, 1987 apud CAUDURO, 1996, p 67). As percepções, portanto, inscrevem-se no universo subjetivo composto na vivência de cada indivíduo e em sua relação histórica com o meio em que vive. Mais além, tal inscrição provoca a ambiguidade, uma imprecisão entre o objeto, a percepção desse objeto e a estruturação do pensamento. Assim, ocorre a diferença na construção de sentido do ser diante do mundo que se lhe apresenta.

É na dupla distância, entre a imagem e aquilo que ela representa e a imagem e o ser que a olha, em que se encontram, concomitantemente, o sentido e a perda: a construção do sentido do que é representado por meio de um discurso articulado pela cultura e pela perda do objeto/sujeito em sua existência causada pela opacidade de sua representação. Deste modo, a construção de imagens é compreendida como processos de (re)conhecimento pelos quais se desenvolvem as condições de pertença e estranhamento do ser e sua relação com a realidade. 
A construção poética do objeto artístico, segundo Guattari, traz a potência de desconstrução dos enunciados generalizantes, uma vez que oferece ao espectador uma distorção do sistema de significados consolidados na/pela atual cultura globalizada, ampliando as possibilidades sensíveis dos indivíduos. Tal objeto, mesmo sendo trivial, exibe a alteridade, uma vez que a estética artística contemporânea constitui-se, no entendimento de Ferry (2003, p 31), como uma extensão do próprio artista, "uma espécie de cartão de visita particularmente elaborado", pelo qual se apresentam "como outros tantos 'pequenos mundos perceptivos' que não representam já o mundo, mas o estado de forças vitais de seu criador" (FERRY, 2003, p. 32).

Considerando tais perspectivas, busca-se aqui analisar a visualidade criada sobre "ser brasileiro" nas imagens fotográficas produzidas por André Cepeda e Miguel Valle de Figueiredo, autores portugueses que realizam trabalhos artísticos e jornalísticos, respectivamente. No que diz respeito a André Cepeda, a escolha orientou-se pela visível autonomia do trabalho do autor, característica da produção artística contemporânea, que o faz ser disponivel à experiência e à conceptualização, nos discursos criados a partir das realidades fotografadas, consistindo uma presença que interroga o próprio olhar do espectador sobre a realidade das coisas ali registradas. Tal posicionamento contrapõe-se ao registro de Miguel Valle, cujas proposições fotográficas relacionam-se, inicialmente, ao olhar publicitário, que busca provocar o consuno, propondo ao consumidor uma experiência no mundo estetitizado do capitalismo artista $^{6}$ (LIPOVETSKY; SERROY, 2015, p. 62).Neste artigo, conforme já explicitado, interessa refletir sobre as referências responsáveis pelas estereotipias acerca da identidade brasileira e que estão conformadas nas imagens coloniais, verificando como isso influencia o reconhecimento do brasileiro na contemporaneidade, no caso expresso, por meio dos olhares desses fotógrafos.

A escolha desses dois fotógrafos visa, ainda, a uma aproximação sobre o modo como é percebido o ser brasileiro na fotografia dos estrangeiros atualmente, especificamente, por portugueses, devido às relações coloniais com o Brasil. Tem-se em conta que, segundo as reflexões pós-modernas da fotografia, cada imagem se referencia a outras, construindo paralelos, diacronias, sincronias e dialéticas, urdindo uma teia de significância cujo resultado está além da intencionalidade do autor. Nessa perspectiva, "as fotografias foram vistas como si- 
nais que adquiriram seu valor a partir de sua inserção no bojo de um sistema mais amplo de codificações sociais e culturais" (COTTON, 2013, p. 191). É assim que aqui se entendem os trabalhos apresentados: como parte de uma grande tessitura histórica, social e política da qual emergem diferentes relações, incluindo as coloniais.

\subsection{André Cepeda, Rua Stan Getz (2014)}

André Cepeda (nascido em Coimbra, 1976) vive e trabalha no Porto. Desde 2005, tem trabalhado muito com a paisagem contemporânea portuguesa, particularmente no Porto, onde mora. O fotógrafo utiliza a câmera de grande formato $(4 \mathrm{~m} \mathrm{x}$ $5 \mathrm{~m}$ ) porque, além de ser, em sua opinião, mais precisa e permitir uma técnica acurada, ela requer um processo lento de trabalho, determinando assim o seu método: uma longa e atenta observação das coisas que o permite se conectar e/ou se relacionar com o objeto ou paisagem que deseja fotografar.

O fotografo afirma, em seu sítio na internet ${ }^{7}$, que está interessado em construir novas formas de olhar a realidade e o espaço que são apresentados a ele. Há, em essência, uma procura por espaços e momentos que têm sido rejeitados, sugerindo uma certa suspensão. O interesse do artista, portanto, se baseia no sentimento que o torna obrigado a criar uma imagem e relatar o seu espaço, tentando esquecer sua história e o contexto original de recepção. Dessa forma, seu único foco é a luz, o espaço e o tempo. Assim, o autor se sente mais livre para criar novos contextos para as imagens, como se esse tratamento quase escultural retomasse uma dignidade que foi renegada ao objeto/paisagem. Para o fotógrafo, essas imagens se tornam um momento de reflexão mais ampla sobre a maneira como construímos nossa identidade cultural, social e política. Cepeda tem interesse no tempo presente, na crise (econômica), na instabilidade e na incerteza, em momentos que não pertencem à história, ou seja, momentos rejeitados, mostrando coisas comuns a todos os lugares, mas que são dificilmente selecionadas e interpretadas.

O autor constrói narrativas reunidas em projetos distintos que, no dizer de Siza, o colocam em uma "linha neobarroca", reconhecendo-o mais do que como fotógrafo, como artista plástico, "em cujas obras o simbolismo da recuperação funciona como arquétipo do sentimento, sem invalidar a fugacidade que proporciona a indeterminação da ação ou do significado" (SIZA, 2006, p. 71). É por este paradoxo que o trabalho do artista é aqui trazido à reflexão, pois as obras que compõem o projeto Stan 
Getz apresentam imagens banais, cotidianas, mas que não se remetem à obviedade: não existem prédios que fazem referência à memória da cidade de São Paulo; dos corpos nus femininos pouco se sabe, mas suas posições e enquadramentos repetem a alguns referentes na história da arte, deixando em suspenso, ou melhor, em aberto, a construção do sentido. Ao tratar de um outro trabalho do artista na cidade do Porto, em Portugal, De Araújo reflete que essa "postura, algo ambígua, permite a interpretação de que o fotógrafo pretende inibir-nos de fazer juízos acerca das pessoas que retrata ou, quando muito, nos pretende mostrar que, aparte a sua história de vida e condição, elas não são diferentes de nós" (DE ARAÚJO, 2012, p. 15)

O trabalho do artista na cidade de São Paulo, no Brasil, logrou três meses ${ }^{8}$ de olhares e percursos que o levaram a uma cidade peculiar. Trata-se de um trabalho mais escultural, que relata o espaço selecionado pelo fotógrafo. As imagens realizadas misturam a experiência de flânerie do fotógrafo que exibe ruas, transeuntes, paisagens, reflexos do espaço da cidade na lente do fotógrafo a registrar seu olhar sobre o caminho construído: "I want the streets to speak to me and teach me how to observe and tell me how I should act", diz o artista. Seu aprendizado resulta em uma série de imagens que constroem para o espectador uma São Paulo que enfrenta a outra: uma da escala do pedestre - atento àquilo que é unico e que surge como surpresa e àquilo que ecoa, repetindo-se - e uma outra escala que apanha a cidade do alto, revelando-a como muitos já a viram. Tais enquadramentos expressam, de um lado, fragmentos da cidade que podem ser vistos de modo generalista, sem a presença das peculiaridades identitárias, e, de outro, a visualidade criada sobre São Paulo. Entretanto, o contraste entre uma e outra escala dimensiona o indivíduo na cidade: a megalópole que abriga o corpo na estreiteza do cotidiano, na dimensão da experiência e não de sua estetização.
Figura 4

Projeto Rua Stan Getz

\section{Figura 5}

Projeto Rua Stan Getz

Fonte: CEPEDA, André (2015). Disponivel em: $<w w w$ andrecepeda.com>. Acesso em: 5 maio 2017
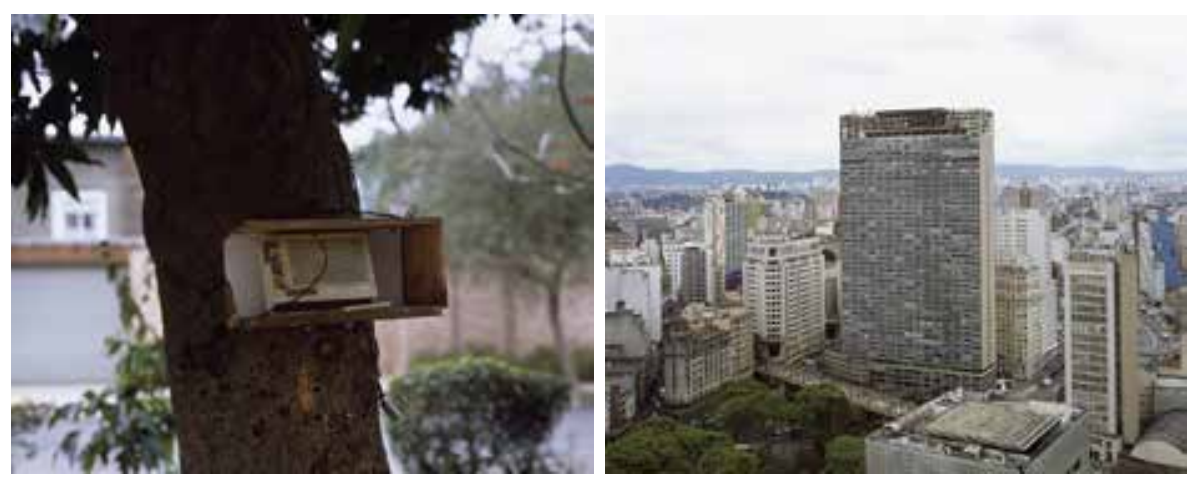

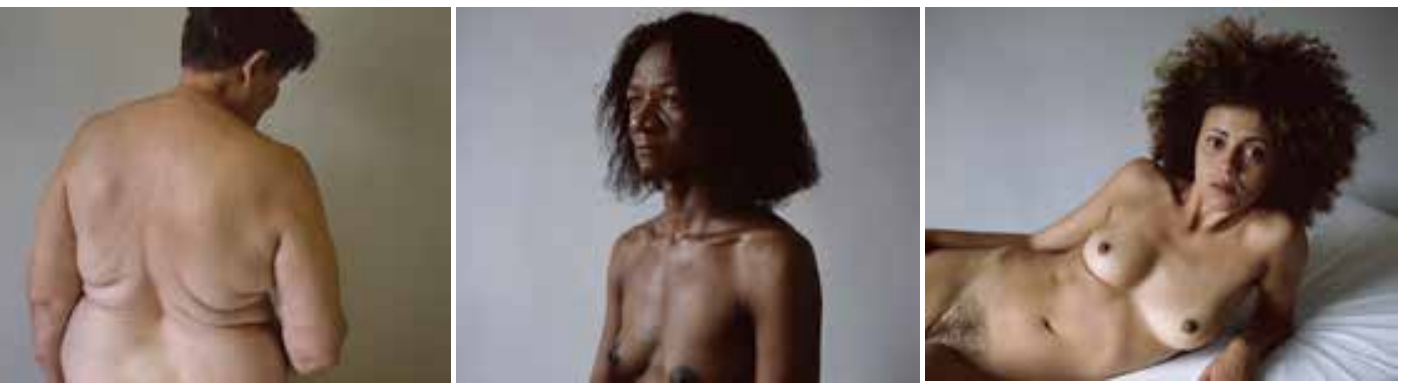

Figura 6, Figura 7, Figura 8 Projeto Rua Stan Getz

Fonte: CEPEDA, André (2015). Disponível em: <www.andrecepeda.com>. Acesso em: 5 maio 2017

Figura $9 e$ Figura 10

Projeto Rua Stan Getz

Fonte: CEPEDA, André (2015). Disponível em: <www.andrecepeda.com>. Acesso em: 5 maio 2017
As fotografias acima constam do livro Rua Stan Getz, de 2015, que também apresenta retratos, na sua maioria, de mulheres nuas. São mulheres de corpos peculiares, construindo a ideia da diversidade étnica e que remetem ao discurso da sensualidade da mulher brasileira há tempos construído.

Impõe-se ainda, ao juízo do espectador, uma única figura masculina do livro, que está vestida. A julgar pelo pensamento de Cotton (2013, p.191), expresso acima e que cabe aqui repetir, a imagem adquire seu valor "a partir de sua inserção no bojo de um sistema mais amplo de codificações sociais e culturais". Constitui-se, assim, um estranhamento causado ao espectador pelo constraste do nu feminino e do homem vestido e que rememora a relação do colonizador com o colonizado, enfrentando-a pela conformação das imagens dada pelo fotógrafo.

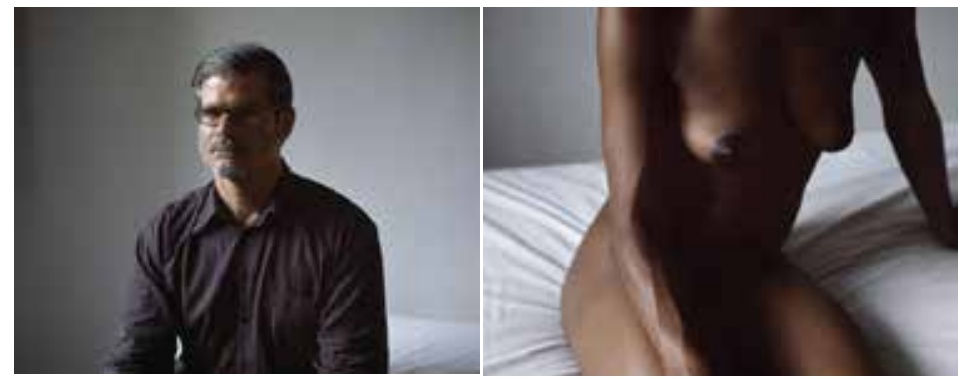

À carta de Caminha sobre as frutas que encontrou no território brasileiro, o autor responde com uma imagem da fruta apodrecida, como que a dizer que o que aqui se encontra nem sempre corresponde ao desejo daquele que aqui vem. Ao mesmo tempo, o fotógrafo parece compor uma natureza-morta que se insere no contexto contemporâneo das fotografias que Cotton (2013, p. 115) classifica como "Alguma coisa e nada", em 
que o artista dirige ao espectador imagens de coisas que, de início, aparentam não ter relevância necessária para que se tornem fotografáveis. São imagens que remetem a uma linha de trabalho em que "os fotógrafos vêm pesquisando a criação de obras das quais estão ausentes os sinais mais gritantes de habilidade técnica" (COTTON, 2013, p. 116).
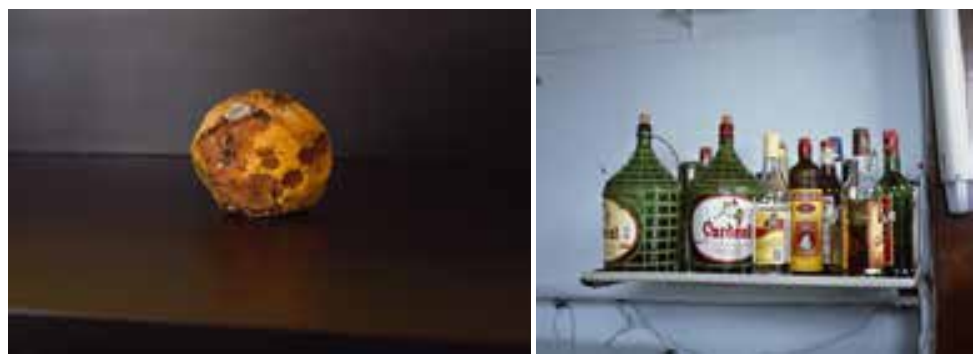

Numa possível construção de sentido, o precário, o provisório, a gambiarra brasileira são expostos nessas fotografias que se constrastam a outras do mesmo projeto. As cores respondem pelos climas vividos na cidade: nada do clima tropical e paradisíaco que povoa o imaginário sobre o Brasil.
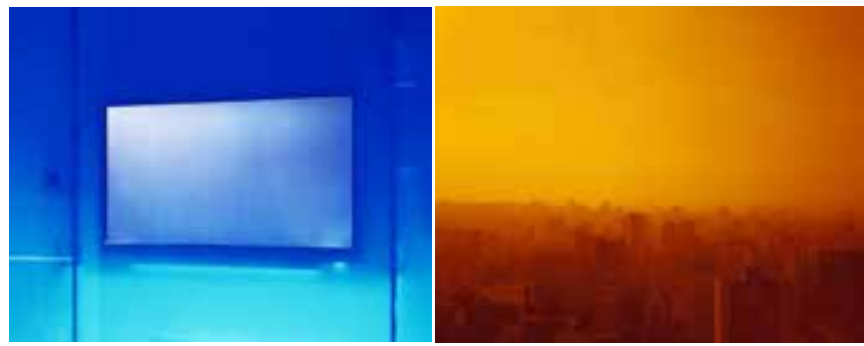

Muitos dos projetos de André Cepeda localizam-se dentro de um viés autoral marcado pelo incentivo a uma visualidade do cotidiano, do banal, sem, no entanto, explicitar a realidade, mas apenas sugeri-la, como nos diz De Araújo (2012). As fotografias do projeto Rua Stan Getz não fogem a essa sutileza. Porém, tal discrição não se sobrepõe à histórica construção de visualidade sobre o "ser brasileiro", pela qual se pode atribuir, da natureza-morta às garrafas de cachaça, passando pelos corpos nus, a presença do exotismo, da folia e da entrega à sen-

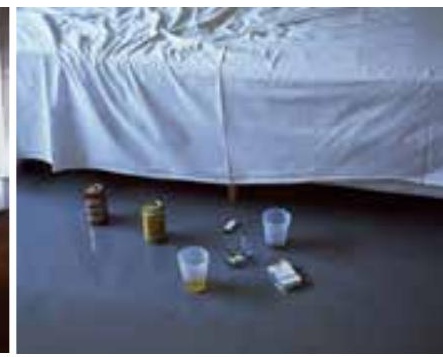

Figura 11, Figura 12 e Figura 13

Projeto Rua Stan Getz

Foto: CEPEDA, André (2015).

Disponível em: $<w w w$.andrecepeda.com>. Acesso em: 5 maio 2017

Figura 14 e Figura 15

Projeto Rua Stan Getz

Fonte: CEPEDA, André (2015).

Disponivel em: $<w w w$ andrecepeda.com>. Acesso em: 5 maio 2017 
sualidade. Entretanto, como é próprio do trabalho do artista, tal rememoração não encerra um julgamento, "quando muito, nos pretende mostrar que, aparte a sua história de vida e condição, [tais pessoas e realidades] não são diferentes de nós" (De Araújo, 2012, p. 15)

\subsection{Miguel Valle de Figueiredo}

Miguel Valle de Figueiredo nasceu em Santa Comba Dão, no distrito de Viseu, Portugal. É fotografo profissional desde 1986, com trabalhos nas áreas industrial, de engenharia/arquitectura e editorial. Em 1994, foi cofundador da revista Volta ao Mundo, publicação destinada a expor possíveis rumos de viagens, realizando reportagens em mais de 50 países. Foi também diretor de fotografia da revista Evasões, no período de 1999 a 2002, dedicada à divulgação do turismo em Portugal e da vida do país. Miguel já veio ao Brasil cerca de 30 vezes, sendo duas dessas vezes de férias. $\mathrm{O}$ autor diz conhecer o Brasil mais que muitos brasileiros, realizando fotografias que compõem revistas e publicações de viagens ou de turismo (Fig. 16). Em 1997, ganhou o prêmio Fuji-European Press Award, na categoria de Grande Reportagem, com uma das fotos realizadas no interior do estado do Ceará, Brasil.

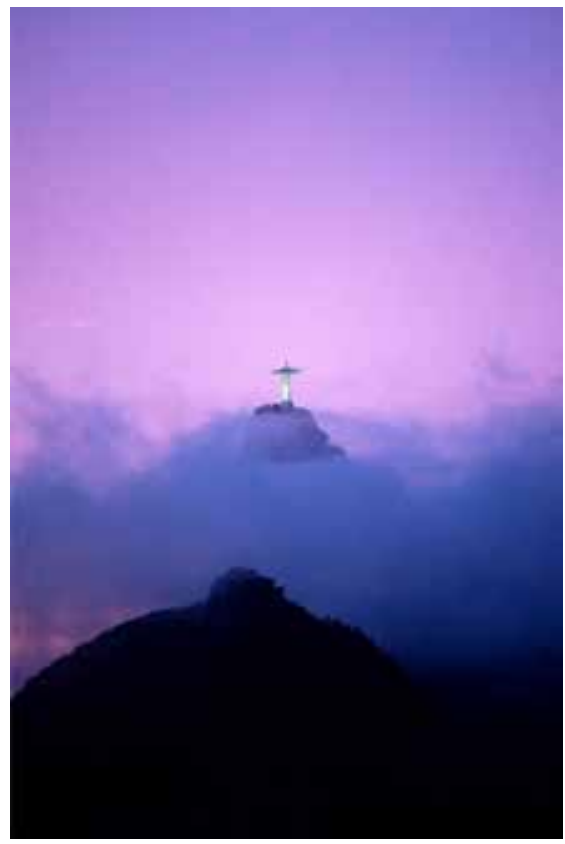


Em conversa com o fotógrafo ${ }^{9}$, ele destaca que suas incursões no Brasil são resultado de trabalhos para publicações turísticas e que, por esse motivo, muitas de suas imagens não fogem da iconografia atribuída ao país tropical de belas paisagens e terra da "garota de Ipanema". Porém, em sua fala, o autor expõe que esse mito sobre a mulher brasileira, criado pelos próprios brasileiros, não existe, pois, na extensão do país, cada brasileira é uma - com suas peculiaridades no andar, no falar, no agirO autor, porém, fotografou peculiaridades de um Brasil continental e desigual. Parece que, ao nos trazer a especificidade de pequenos vilarejos do Nordeste e de seus habitantes, acentua essa desigualdade e escancara um país não mais tão generoso em recursos como a carta de Caminha anunciou em seu início. A conquista da natureza paradisíaca gerou, de fato, vários brasis. Esse Brasil, exibido nas fotos premiadas do fotógrafo, reforça a ideia do país mestiço e apresenta os paradoxos e contrastes nos modos de viver dos indivíduos e das sociedades que compõem a nação.
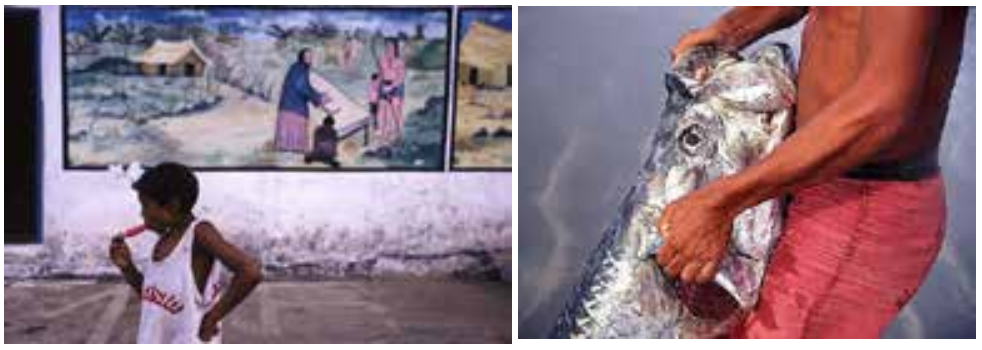

Dizendo que não consegue "estabelecer aquilo que é o brasileiro, enquanto objeto de retrato", o fotógrafo diz que tal afirmação "não é a mesma coisa de dizer que" não consiga “fotografar os diversos brasileiros, como 'o' brasileiro”. Faz referência, ainda, aos vários tipos que há no Brasil, pois não há como traduzir "duzentos milhões de pessoas com tanta variedade" e conclui: "A lógica rácica no Brasil é muito difícil de mapear fotograficamente".

Nas fotos premiadas, no entanto, estampam-se os indivíduos de uma coletividade parda, à qual o autor assim se refere:
Figura 17 e Figura 18 Nordeste brasileiro

Fonte: Valle de Figueiredo, Miguel (2009).

Disponível em: http://www.flickr. com/photos/miguelvf/ sets/72157608327391297/.

Acesso em: 10 de novembro de 2015

Eu fico espantado com o pardo, o que é isso do pardo? Isso é que eu acho que um critério completamente racista. [...] Por isso que eu tava falando das questões d'algum racismo forte- 
mente implantado no Brasil, a todos os níveis, [...] deixa me pouco à vontade. Sem crítica, pelo amor de Deus. Mas deixa-me espantado como é que um país tão miscigenado tem isso tão forte, tão forte ${ }^{10}$.

Conclui-se, assim, com base na apreciação das imagens atravessadas pela fala do artista, que sua escolha não se dá objetivamente por uma identidade, por definir quem seria o brasileiro, mas apresentar um possível brasileiro. Embora fotografando cenas cotidianas das comunidades visitadas e sendo as imagens povoadas por indivíduos, aquilo que se apresenta ao espectador é uma cultura, uma estrutura sobre a qual esses indivíduos mantêm suas relações com o mundo que o cercam, inclusive quanto à sua necessidade de subsistência.

Figura 19

Nordeste brasileiro

Fonte: Valle de Figueiredo, Miguel (2008).

Disponível em: <https://www. flickr.com/photos/miguelvf/ sets/72157608327391297/>. Acesso em: 10 nov. 2015

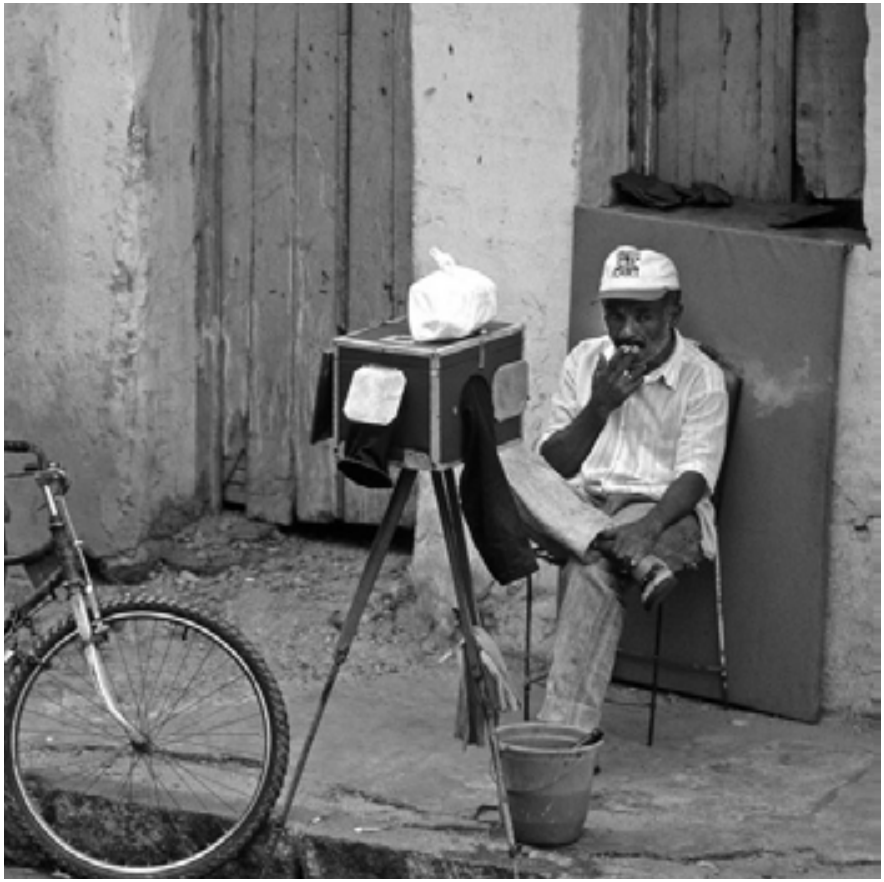

Nas imagens do Nordeste brasileiro, o caráter jornalístico é marcante, e é este princípio que conduz a lente do fotógrafo. O recorte da realidade forma um discurso sobre o Brasil, e o autor parece reforçar tal ação de recortar por meio das escolhas do enquadramento. Por estas, deixa-se claro que há mais 
para se ver do que aquilo que é mostrado. Nas imagens acima (Figuras 16 e 17), o corpo do menino a chupar picolé e o do homem a segurar o peixe, bem como a bicicleta e a casa das quais só aparecem partes (Figura 18), parecem nos sugerir que há muito mais a ver e conhecer desse país, dessa cultura.

Curiosamente, a pintura atrás do menino com o picolé registra a colonização e a conversão do povo encontrado pelos portugueses, os indígenas. Tal passado representado às costas do menino, que é mestiço, consegue dar à fotografia uma profundidade histórica que se delineia na estrutura social, bem como na pele do brasileiro. Ela expõe os vestígios da presença europeia. À época em que as fotos foram feitas, o local era pouco habitado e pouco visitado por turistas, de modo que não havia ainda a transformação da experiência e da arquitetura da cidade. A citada imagem de fundo remete ainda à exploração sexual de crianças tanto pelo colonizadores como pelos turistas na época atual, prática difícil de ser combatida devido à pobreza da região.

\section{Considerações finais}

Os trabalhos dos fotógrafos apresentados figuram como possibilidade de reflexão sobre uma visualidade historicamente criada e que continua a pontuar imaginários sobre a constituição da identidade brasileira. Tal visualidade, longe de construir diálogos sobre essa identidade, apresenta-se como urdidura de uma estrutura de subjugo, representando e acentuando as relações desiguais que se estabeleceram anteriormente e que são reforçadas no atual mundo globalizado. Cada imagem é absorvida num regime de valores apropriador e classificatório, alargando e reproduzindo relações assimétricas de poder.

As fotografias de Miguel Valle de Figueiredo realizadas com objetivo de divulgar turisticamente o Brasil publicizam uma terra de belezas e prazeres. Tal pano de fundo constrasta-se ao discurso de pobreza e atraso do país apresentado nas imagens jornalísticas das Figuras 16 a 18, que tratam de lugares que permanecem longe da modernidade, em uma atividade principalmente extrativista e agrária, igualmente àquela do início da colonização do país, citada por Freyre (2003, p. 8687): "Terra e homem estavam em seu estado bruto. Suas condições de cultura não permitiam aos portugueses vantajoso intercurso comercial que reforçasse ou prolongasse o mantido por eles no Oriente". As fotografias parecem rememorar e re- 
forçar a ausência de desenvolvimento de um país que permanece no passado e que, mesmo em seus esforços, não supera o estereótipo de ser uma terra e um povo colonizados.

De sua parte, André Cepeda insinua relações entre espectador e obra, tratando da banalidade cotidiana, contrastando a perspectiva da rua e do interior, do público e do privado. As duas esferas, porém, apresentam generalizações de tal modo que o espectador não possa identificar, facilmente, os lugares e suas peculiaridades. Mesmo os ambientes internos são impessoais: o lugar é branco, mas marca, mesmo sem o corpo, a presença do humano: a cultura e as visualidades construídas sobre o Outro. Em seus trabalhos, o fotógrafo constitui o que há de comum entre o que é visto e aquele que olha. Não é diferente no projeto realizado no Brasil. O que poderia marcar uma diferença são os discursos historicamente construídos sobre a brasilidade. O que importa, nesse caso, é quem olha.

A formação de uma visualidade sobre os aspectos culturais e a identidade brasileira é baseada em um campo semiótico determinado por signos (palavras) que se propõem a nomear os modos e as relações estabelecidos no Brasil e que circulam em torno do prazer, da precariedade, da violência, da indolência e da sensualidade. Nesse perspectiva, essas palavras parecem estar impregnadas de um colonialismo ativo e somam-se às diversas linhas de ação de domínio e agenciamento de desejos dos próprios brasileiros. A visualidade torna-se uma espécie de estratégia de controle e manutenção de um sistema que, por conseguinte, conformará as realidades que se pretende estabelecer. Assim, como coloca Mirzoeff (2003, p. 27), "a cultura visual é uma tática [...] e a tática é uma manobra que se realiza à vista do inimigo controlado na sociedade em que vivemos. [...] Também se pode argumentar que as táticas são necessárias para evitar a derrota nas guerras culturais em curso".

Os discursos imagéticos criados pelos fotógrafos portugueses citados dialogam com uma visualidade historicamente criada, que pretende continuar a delinear a identidade brasileira pela presença da sensualidade exacerbada, do exotismo e da alegria. É necessária, portanto, a sobreposição desses discursos pela crítica atual aos neocolonialismos, ou seja, o questionamento sobre as bases nas quais esses discursos se apoiam, considerando os elementos escolhidos pelos fotógrafos e que compõem as imagens que expressam sua versão de brasilidade. Dessa maneira, intenta-se provocar o estranhamento às imagens, podendo gerar paradoxos sensíveis a essa visualidade e deixando surgir a complexidade existente na formação da identidade brasileira. 
1 "Desenvolvidas pelo francês André Disdéri, no ano de 1854, as cartes de visite são fotografias que carregam dentro de si a função de ampliar o campo de ação dos retratos fotográficos, fazendo isto com o uso de novas formas de uso das técnicas já existentes, como o negativo de vidro em colódio úmido e a cópia em papel albuminado." LEITE, Marcelo Eduardo. As fotografias cartes de visite e a construção de individualidades. Interin: Revista do Programa de Pós-Graduação em Comunicação e Linguagens, Universidade Tuiuti do Paraná, v. 11, n 1, p. 1-16, jan./jun 2011. Disponível em <http://interin.utp.br/ index.php/volı1/article/viewFile/42/34> Acesso em: 26 out. 2016.

2 Tem-se em conta que, apesar de este artigo tratar de um determinado aspecto da fotografia colonial, as discussões sobre esse conceito avançam e ainda não se tem ao certo o delineamento de tal assunto. Ver <http://photoclec.dmu.ac.uk/content/colonial-photographs $>$.

3 Exposição realizada no Museu Nacional de Arte Contemporânea do Chiado, Lisboa, Portugal, de 13 mar. a 18 mai. 2014.

4 "Processo fotográfico que emprega negativos de vidro de colódio úmido, subexpostos e montados sobre fundo negro para produzir o efeito visual de positivos. [...] opção mais barata para o daguerreótipo, o ambrótipo era apresentado nos mesmos estojos luxuosos. Muito empregado para retratos entre 1850 e 1860, o ambrótipo [era] ocasionalmente denominado de melanótipo no continente europeu." Enciclopédia Itaú Cultural. Disponível em < http:// enciclopedia.itaucultural.org.br/termo72/ambrotipo >. Acesso em: $12 \mathrm{mai}$ 2017.

5 Termo criado por Jacques Derrida no artigo "La différance", em Théorie d'ensemble, França: Ed. du Seuil, 1968. O autor "quer distinguir a diferença conceitualizável no senso comum de uma diferença que não é trazida de volta para a ordem desse mesmo senso comum e, mediante um conceito, recebe identidade. Diferença, nessa acepção, não é identidade; nem é a diferença entre duas identidades". LETCHE, John. Cinquenta pensadores contemporâneos essenciais. Rio de Janeiro: Difel, 2002. p. 126.

6 O capitalismo artista não só desenvolveu uma oferta proliferante de produtos estéticos, como criou um consumidor faminto de novidades, de animações, de espetáculos, de evasões turísticas, de experiências emocionais, de fruições sensíveis: em outras palavras, um consumidor estético ou, mais exatamente, transestético (LIPOVETSKY; SERROY, 2015, p. 62).

7 http://www.andrecepeda.com/.

8 Informação retirada do texto "São Paulo em corte", de Agnaldo Farias, disponível no site do artista: <http://www.andrecepeda.com/projects/sao-paulo-em-corte/>.

9 Entrevista concedida no dia 10 de agosto de 2016, na Fundação Calouste Gulbenkian, a Lorena Travassos.

10 Idem

\section{Referências}

ALVES, Jorge F. O «brasileiro» oitocentista - representações de um tipo social. In: VIEIRA, Benedicta Maria Duque (Org.). Grupos sociais e estratificação social em Portugal no século XIX. Lisboa: ISCTE (C.E.H.C.P.), 2004. p. 193-199 
ARAÚJO, Vasco. Exposição Botânica. 2014. Disponível em $<$ http://vascoaraujo.org/Botanica>. Acesso em: 2 set. 2016

ARROYO, Leonardo. Pero Vaz de Caminha: carta ao El Rei D. Manoel. São Paulo: Dominus, 1963.

BARRADAS, Carlos. Poder ver, poder saber. A fotografia nos meandros do colonialismo e pós-colonialismo. Arquivos da $\mathrm{Me}$ mória: Antropologia, Arte e Imagem, n. 5-6, p. 59-79, 2009.

BRAGA, Ruy. Globalização ou neocolonialismo? O FMI e a armadilha do ajuste. Revista Outubro, edição 4, 2000, p. 55-68. Disponível em: <http://outubrorevista.com.br/>. Acesso em: 19 set. 2016.

BARTHES, Roland. A câmara clara. Rio de Janeiro: Nova Fronteira,1984.

BENJAMIN, Walter. Sobre arte, técnica, linguagem e política. Tradução de Maria Amélia Cruz et al. Lisboa: Relógio D’Água, 1992.

CAUDURO, Flávio V. Escrita e différance. Revista FAMECOS, Porto Alegre, n. 5, p. 63-72, 1996. Disponível em: <http:// revistaseletronicas.pucrs.br/ojs/index.php/revistafamecos/article/view/2949/2233. > . Acesso em: 19 set. 2016.

CAVALCANTE, R. A cara do brasileiro. Super Interessante, São Paulo, n. 217, p. 68-74, set. 2005.

CEPEDA, André. Rua Stan Getz. Lisboa: Pierre Von Kleist Editions, 2015.

. Rua Stan Getz. Disponível em: <www.andrecepeda. com>. Acesso em: 28 mar. 2016.

COTTON, Charlotte. A fotografia como arte contemporânea. São Paulo: Martins Fontes, 2013.

CUNHA, Manuela C. Olhar escravo, ser olhado. In: LISSOVSKY, Paulo C. de A. M. (Org). Escravos brasileiros do século XIX na fotografia de Christiano Jr. São Paulo: Editora Ex Libris, 1987. p. xxiii- xxx.

DAMATTA, R. O que faz o brasil, Brasil? Rio de Janeiro: Editora Sala, 1984.

DE ARAÚJO, Nuno Borges. Duas fotografias de André Cepeda. Encontro de Paisagens, p. 13-17, 2012.

DERRIDA, Jacques. La différance, conférence prononcée à la Société française de Philosophie, le 27 janvier 1968. In : Théorie d'ensemble. Paris: Ed. Seuil, 1968. p. 41-66. (Coll. Tel Quel). Disponível em: <http://ionas-editions.com/ fr/2016/05/27/1968-jacques-derrida-la-differance-2/> Acesso em: 15 out. 2016.

EWING, Willian A. The body: photoworks of the human body. London: Thames \& Hudson, 1996. 
FARIAS, Agnaldo. São Paulo em corte. 2013. Disponível em: $<$ http://www.andrecepeda.com/projects/sao-paulo-em-corte>. Acesso em: 26 ago. 2016.

FERRY, Luc. Homo Aestheticus - a invenção do gosto na era democrática. Coimbra: Almedina, 2003.

FREITAS, Marcel de A., O cotidiano afetivo-sexual no Brasil colônia e suas consequências psicológicas e culturais nos dias de hoje. Ponta de Lança: Revista Eletrônica de História, Memória \& Cultura, Universidade Federal de Sergipe, v. 5, n. 9, p. 63-58, 2011. Disponível em: <http://www.seer. ufs.br/index.php/pontadelanca/article/view/1577/2710>. Acesso em: 13 ago. 2016.

FREYRE, Gilberto. Casa-grande E senzala. 48 ed. São Paulo: Global, 2003. [Apresentação de Fernando Henrique Cardoso].

GORENDER, Jacob. A face escrava da corte imperial brasileira. In: LISSOVSKY, Paulo C. de A. M. (Org). Escravos brasileiros do século XIX na fotografia de Christiano Jr. São Paulo: Editora Ex Libris, 1987. p. xxxi-xxxvi.

GIL, Isabel C. Literacia visual - estudos sobre a inquietude das imagens. Lisboa: Edições 70, 2011.

GUATTARI, Felix. Caosmose. Um novo paradigma estético. São Paulo: Ed. 34, 1992.

HALL, Stuart. The work of representation. In: HALL, Stuart (Org.) Representation. Cultural representation and cultural signifying practices. London/Thousand Oaks/New Delhi: Sage/Open University, 1996.

HALL, Stuart. Cultural identity and diaspora. In: MIRZOEFF, Nicholas (Org.), Diaspora and visual culture: representing Africans and Jews. Londres e Nova Iorque: Routledge, 2000, p.21-33.

HOLANDA, Sérgio B. Raízes do Brasil. Brasília: Universidade de Brasília, 1963.

JENKS, X. Visual culture. Londres: Routledge, 1995.

LEITE, Marcelo Eduardo. As fotografias cartes de visite e a construção de individualidades. Interin: Revista do programa de Pós- Graduação em Comunicação e Linguagens, Universidade Tuiuti do Paraná, v. 11, n 1, p. 1-16, jan./jun. 2011. Disponível em: <http://interin.utp.br/index.php/volı/article/viewFile/42/34>. Acesso em: 26 out. 2016.

LETCHE, John. Cinquenta pensadores contemporâneos essenciais. Rio de Janeiro: Difel, 2002.

LIPOVETSKY, Gilles; Jean SERROY. A estetização do mundo: viver na era do capitalismo artista. São Paulo: Companhia das Letras, 2015. 
LISSOVSKY, Maurício; AZEVEDO, Paulo. C. O fotógrafo Cristiano Jr. In: LISSOVSKY, Paulo C. de A. M. (Org). Escravos brasileiros do século XIX na fotografia de Christiano Jr. São Paulo: Editora Ex Libris, 1987. p. ix-xv.

MIRZOEFF, Nicholas. Una introducción a la cultura visual. Barcelona: Paidós, 2003.

NARANJO, Juan. Fotografía, antropología y colonialismo (1845-2006). Barcelona: Colección FotoGGrafia, 2006.

PONTES, Luciana. Mulheres brasileiras na mídia portuguesa. Cadernos Pagu, n.23, p.229-256, jul./dez. 2004. Disponível em: $<$ http://www.scielo.br/scielo.php?script=sci_serial\&pid=0104-8333\&lng=en\&nrm=iso $>$. Acesso em: 21 nov. 2013.

RIBEIRO, Darcy. O povo brasileiro: a formação e o sentido do Brasil. São Paulo: Companhia das Letras, 1995.

ROBERTS, A. Photographs as sources for African history: papers presented at a workshop held at the School of Oriental and African Studies. London: Soas, 1988

SANTOS, Boaventura de Sousa; NUNES, João Arriscado. Introdução: Para ampliar o cânone do reconhecimento, da diferença e da igualdade. In: SANTOS, Boaventura de Sousa (Org.). Reconhecer para libertar: Os caminhos do cosmopolitismo multicultural. Porto: Edições Afrontamento, 2004. p. 19-51

SIZA, Teresa. El arte como límite fotografía contemporánea portuguesa. Minerva, v. 4, n. 2, p. 70-73, 2006.

VALLE DE FIGUEIREDO, Miguel V. de. O trabalho fotográfico - uma incursão no Brasil. Entrevista concedida a Lorena Travassos. Lisboa, ago. 2016.

In Memoriam, 2009. Disponível em: <https:// br.pinterest.com/pin/315885361336668929/>. Acesso em: 12 ago. 2016.

. Nordeste brasileiro. Disponível em: <https://www. flickr.com/photos/miguelvf/sets/721576o8327391297/>. Acesso em: 22 ago. o16.

VANIFAS, Ronaldo. Moralidades brasílicas. In: NOVAIS, F. A. (Coord.). História da vida privada no Brasil. São Paulo: Companhia da Letras, 1997.

VICENTE, Felipa (Org.). O império da visão: fotografia no contexto colonial português: (1860-1960). Lisboa : Edições 7o, 2014.

Recebido em: 27/10/2017

Aprovado em: 01/03/2018 


\section{CRISTIANE HERRES \\ crisherres@gmail.com}

Docente em Artes Visuais no Instituto Federal de Brasília; pesquisadora (DGP/CNPq/Brasil), Doutora em Arte pelo PPG-IdA/UnB Brasil.

\section{LORENA TRAVASSOS}

lorenakrs@gmail.com

Mestre em Comunicação (UFPB - Brasil), Doutoranda em Ciências

da Comunicação na Universidade Nova de Lisboa (FCSH-UNL), Investigadora do CIC-Digital / UL, bolsista da CAPES - Brasil. 
